\title{
The Art of the Nouveau Roman in The Driver's Seat
}

\author{
Hongbin Dai ${ }^{1}$, Xiying Liu ${ }^{2}$ \\ ${ }^{1}$ Xiamen University, Xiamen, China. \\ ${ }^{2}$ Central China Normal University, Wuhan, China. \\ Correspondence: Xiying Liu, Central China Normal University, Wuhan, China. \\ Received: November 25, 2015 \\ Accepted: December 9, $2015 \quad$ Available online: December 10, 2015 \\ doi:10.11114/ijsss.v4i1.1244 \\ URL: http://dx.doi.org/10.11114/ijsss.v4i1.1244
}

\begin{abstract}
This article focuses on Muriel Spark's art of the nouveau roman in The Driver's Seat. It probes into the nature of the nouveau roman, the major concerns of its advocates, and the relation between the nouveau roman and postmodernism. Then it tackles with the presentation of the protagonist, the descriptions of the places, monotonous behaviour of the characters and the purposeful design of the lack of syntactical variety. Finally, it discusses the disruption of the sequential plot. With the impersonal narration and the rejection of the sequential plot, Spark's The Driver's Seat shows the typical features of the nouveau roman as well as the postmodernist fiction and turns out to be a brilliant success.
\end{abstract}

Keywords: Muriel Spark, The Driver's Seat, Art of the Nouveau Roman

\section{Introduction}

Muriel Spark (1918-2006) was considered by David Lodge to be "the most gifted and innovative British writer of her generation" (Hosmer, 2005: p. 127). Her masterpiece The Driver's Seat was shortlisted for the "Lost Booker McConnel Prize" in the year 2010, which was to reward the fiction published in 1970 that "fell through the net", because since 1971, the Booker Prize has been given to the best novel of the current year. It was the third time Muriel Spark was shortlisted for the Booker Prize, the first two times respectively in 1969 and 1981. This article focuses on Muriel Spark's art of the nouveau roman in The Driver's Seat. The first part probes into the nature of the nouveau roman, the major concerns of its advocates, and the relation between the nouveau roman and postmodernism. The second part tackles with the presentation of the protagonist, the descriptions of the places, monotonous behaviour of the characters and the purposeful design of the lack of syntactical variety. The third part discusses the disruption of the sequential plot, which is another main feature of the nouveau roman, from the perspectives of the predominant use of the present tense and the application of the unusual time shift called "flash-forwards".

\section{The Nature of the Nouveau Roman and its Relation with Postmodernism}

"Nouveau roman" is a French term, "applied since the mid-1950s to experimental novels by a group of French writers who rejected many of the traditional elements of novel-writing such as the sequential plot and the analysis of characters' motives" (Baldick, 2000: p. 151) The leading light of the group, Alain Robbe-Grillet, advocates a neutral register of sensations and things. It is universally agreed that the first probable prototype of the nouveau roman is Tropismes published by Nathalie Sarraute in 1939. However, people do not reach a consensus as to the exact date of the first deliberate use of "the nouveau roman" as the term to name what seems to be a new literary group. Nevertheless, it is certain that the phenomenon and development of the nouveau roman were confirmed in the special issue of the review Esprit published in August 1958. The core of the body of works described by the issue as the "nouveau roman" contains: Alain Robbe-Grillet's Les Gommes (1953), Le Voyeur (1955) and La Jalousie (1957), Nathalie Sarraute's Martereau (1954) and L'Ere du Soupçon (1956), Michel Butor's L'Emploi du Temps (1956) and La Modification (1957), Claude Simon's L'Herbe, etc.

Accordingly, it is in the fifties that the idea of the nouveau roman was formulated as well as developed. In the history of the nouveau roman, Alain Robbe-Grillet is a prominent and most influential figure whose works and theoretical writings help to define and discuss the movement, the phenomenon and the significance of the nouveau roman. Spark has more than once admitted her indebtedness to him. Robbe-Grillet's theories were later gathered in Pour un Nouveau Roman (1963) which serves as a guidance to the general writing techniques of the nouveau roman.

The nature and the novelty of the nouveau roman vary according to different critics. One view about the novelty and nature of the nouveau roman contends that it is "a part of a developing tradition in twentieth-century fiction whereby the 
burden of realism is gradually shifted from content to form (and thus renders the form-content distinction redundant)" (Jefferson, 1980: p. 3). This view can be named that of formal realism, which is rational due to its ability to account for the change in the fiction in terms of historical factors. Nevertheless, it has the disadvantage that it defines the novel only by external issues like the economic structure of the society and the nature of human experience, rather than by the genre of novel itself. Another view represented by Ricardou defines it in accordance to its opposition to traditional fiction. He believes that the nouveau roman attempts to overturn the conventions which imply that the novel is a copy of reality and the nouveau roman is constituted instead primarily by writing itself, which produces instead of copying reality. (Jefferson, 1980: p. 4)

Apart from the nature of the nouveau roman, the most often discussed factors concern the plot and the character, the innovative handling of which is the most conspicuous feature of the nouveau roman. Robbe-Grillet has a low opinion of the plot. He argues that the order and coherence of the plot tend to provide a false view of the world as ordered and intelligible. Also, he believes that the plot is not confident or coherent as before, and things happen, but the relation between them is seen to be problematic. (Sturrock, 1969: p. 9).Nathalie Sarraute also talks about plot with a scornful tone. Plot is an artificial form of representation that "by wrapping itself around the character like a bandage, creates an impression of coherence and life, but also gives him the rigidity of a mummy" (Sarraute, 1963: p. 65).

In addition to the issue of the plot, Grillet, Sarraute and Ann Jefferson make some enlightening comments on that of the character. Because of the attack made by Robbe-Grillet and Nathalie Sarraute on it, the character seems to be abolished in the novel, which leads to the elimination of the human factors from the novel. However, the truth is that despite his fierce attack on character, Robbe-Grillet contends that the description of character is only reduced in the novel and the reduction is determined by social changes in the world that we live in: "The character novel belongs well and truly to the past, it typifies a certain era; when the individual were at his height... A character was all the more important as it was also a weapon in any confrontation"(Grillet, 1970: p. 28).

The nouveau roman is closely connected with the term postmodernism, as Edmund Smyth writes in "The Nouveau Roman: Modernity and Postmodernity": "The sustained and systematic assault upon the assumptions and procedures of classic realism, vigorously pursued by the leading nouveaux romanciers, could almost be said to represent a manifesto of postmodern aims and aspirations"( Smyth, 1991: p. 54).

Since the relationship between the nouveau roman and postmodernism is so intimate, what are the postmodernist characteristics of the nouveau roman? As the works of the new novelists show, they demonstrate some measure of dissatisfaction with the previous textual practice, especially with the common practice of coherent narrative. Hence, there is the tendency that nothing of the coherent narrative perspective exists in the nouveau roman, which can be regarded as one important feature of postmodernism. Spark grasps the significance of the tendency and rejects the sequential plot in The Driver's Seat, which reveals her influence by the Nouveau Roman.

The next major postmodernist characteristic of the nouveau roman lies in its special treatment of language. "For a text to be described as a nouveau roman it had to exhibit self-reflexive and metafictional features as well as foreground the exploration of the semantic and phonetic properties of language"(Smyth, 1991: p. 68).

Another postmodernist characteristic of the nouveau roman is the loss of meanings and the dissolution of the depth pattern in the novels. The loss of depth reflects the loss of the traditional value and shows that literature puts its original obligation and tasks to doubt and negates the present order, authority, criteria, and so on. Thus, the world in the fiction often reveals the features of instability, plurality, ignobility, fragmentation, elusiveness, indeterminacy, and inexpressiveness. To dissolve the depth pattern, new novelists usually choose seemingly insignificant and valueless topics and make full use of the device of collage to make up the whole story. It is through the use of the technique of collage that writers disregard the conventional concepts of space and time, subvert the causal logic, and put together the largely unconnected objects with respect to either time or space. They may juxtapose fragments in their consciousness or memory at random to construct their fictional world and express their views. The other form of the loss of the depth pattern involves the elimination of psychological perspectives in the nouveau roman. Again, Spark's purposeful refusal to provide any information of the characters' psychological state in her The Driver's Seat confirms her benefits from the nouveau roman. Writers are inclined to discard the descriptions of the characters' mental or spiritual state which is highly valued as an important aspect of traditional and modern writings. Without the descriptions of the mental state of characters, the novel appears to be lacking in depth, which is paradigmatic of postmodernist writings, and only makes itself interpreted through the impersonal and objective descriptions of the outer appearances of things. This leads to the loss of the subjective consciousness which is the main object of the modernist writers. The loss causes the human-centered point of view to be overturned and produces the subjective fragments that are characteristic of postmodernist writings.

One more postmodernist characteristic of the nouveau roman is the varied strategies it takes advantage of, as is written: 
"Parody, self-quotation, the mixing of writings and culturally defamiliarizing strategies place the nouveau roman firmly within postmodernism" (Smyth, 1991: p. 73). One of the most conspicuous techniques wielded by the new novelists is the mixing of a variety of writings and even the combination of the other genres with fiction. The techniques of the other arts as varied as music, films, drawings, and architecture are made use of in the writings of the nouveau roman. All these show the effects of the other art forms help the new novelists to convey their understandings of the world in fiction, and thus extend the range of fiction.

In general, the nouveau roman is an innovative school of literature whose major concerns involve the perspectives of the character description and the plot design. The nouveau roman places itself in the camp of postmodernism, owing to its incoherent narrative perspectives, its uncommon handling of language, its dissolution of the depth pattern, and the mixing of varied strategies in the novel.

The Driver's Seat by Muriel Spark is immensely influenced by Robbe-Grillet and intimately connected with the nouveau roman. In this novel, Spark demonstrates paradigmatic features of the nouveau roman and proves her competence in the application of the postmodernist art. The typical features of the nouveau roman demonstrated in The Driver's Seat are Spark's impersonal narration of the fiction and her rejection of the sequential plot in the novel.

\section{The Impersonal Writings of the Fiction}

In The Driver's Seat, Spark evidently adopts an impersonal attitude in the presentation of the story, which is a typical postmodernist feature. Her impersonal writings are demonstrated in many ways, such as the conveyance of the sense of detachment, and the presentation of the anonymous protagonist. The impersonal narration of Spark reflects her refusal to reveal any of the feelings or thoughts about the characters and her intentional deviation from either the realist or the modernist writings, thus showing the dissolution of the depth pattern, which is characteristic of postmodernist writings. Furthermore, the distancing effects produced by the impersonal writings stimulate the reader and impel him to actively participate in the reading and interpretation of the novel, thus rendering the novel a "writerly" text instead of a "readerly" text, and showing the postmodernist attributes. Also, the estrangement effects produced by the impersonal attitude would "call attention to the constructedness of the fictional scenarios being portrayed in order to inhibit readerly immersion and promote instead a critical engagement with those situations and events" (Herman, 2008: 477-78), thus manifesting the self-reflexivity of the work and revealing the novel's postmodernist features.

The influence of Robbe-Grillet or the nouveau roman on Muriel Spark has been known for a long time. It was first observed by Frank Kermode in an interview of The Driver's Seat upon its publication in 1970:

Lise, the heroine of this one, starts out from somewhere in the north for a vacation somewhere in the south. Although she speaks four languages we are not told which is her own. As she proceeds on her peculiar pilgrimage we are allowed to observe her closely, but have no other privilege, so that we don't know why she is so upset, whether her hair is tinted, what - till the clues are all puzzlingly planted — she thinks she's doing. From the elaborate description of her flat we may infer that she is very isolated; but her snack on the aeroplane is described with equal intimacy, and so are the bellpushes... In short, there is a strong flavor of nouveau roman. (Kermode, 1970: p. 425)

Spark herself also openly admits her influence by the nouveau roman, or the new novelists, such as Robbe-Grillet and Simon:

Yes, my vision is nearer to Flaubert or Proust or another French writer who has influenced me a great deal, called Robbe-Grillet, and the nouveau roman he wrote which was rather devoid of emotions; devoid of stated emotions, but not devoid of felt emotions that you read between the lines... I'm very influenced by French writers. (Hosmer, 2005: p. 135)

Ever since its publication, The Driver's Seat has enjoyed an excellent reputation. It remains one of Spark's most accomplished works. In 2005, just one year before her demise, Spark still insisted on her former viewpoint on The Driver's Seat: “... I think my best book, my favorite novel , is called The Driver's Seat” (Hosmer, 2005: p. 135).

The Driver's Seat is about an accountant named Lise, who, because of disillusion with life, carefully plans her own murder by someone she chooses. In the first few chapters of the novel, Spark sets the scene in a shop, an airport, the cabin of a plane and the hotel where Lise stays. In all these places, Lise behaves in a peculiar manner, striving to draw people's attention so as to leave some traces for the police to track down.

Later, when Lise goes out, she meets an old woman named Mrs. Fiedke who shares a taxi with her. Fiedke tells Lise that her nephew named Richard is arriving from Copenhagen that evening - It seems to be a coincidence that Lise finally persuades this Richard to murder her-Lise in turn tells her that she wants to meet a friend. They seem to get on well and go shopping together. When they are still in the street, they get caught up in a demonstration in which some 
policemen clash with students and tear-gas is used, so they are separated.

Returning to the hotel, to her surprise, she finds Mrs. Fiedke's nephew who happens to be the one she "picks out" in the aircraft. She doesn't hesitate to order him to follow her to a park in her car that is "borrowed" from Bill. This time, Lise sits in the driver's seat, physically and metaphorically, fully in control of the situation. She leads him to the Pavilion, walks round the back and over to the hedge. And with calmness, she demands the man to murder her:

At first, he is frightened and wants to leave. But he can't resist her control and murders her as she wishes. Before he leaves, he already envisions his future arrest:

He sees already the gleaming buttons of the policemen's uniforms, hears the cold and the confiding, the hot and the barking voices, sees already the holsters and epaulets and all those trappings devised to protect them from the indecent exposure of fear and pity, pity and fear. $(107)^{1}$

The novel contains a lot of external descriptions. For example, when it comes to the room that Lise inhabits, Spark gives detailed descriptions of it:

She has added very little to the room; very little is needed, for the furniture is all fixed, adaptable to various uses, and stackable. Stacked into a panel are six folding chairs, should the tenant decide to entertain six for dinner. The writing desk extends to a dining table, and when the desk is not in use it, too, disappears into the pinewood wall, its bracket-lamp hinging outward and upward to form a wall-lamp. The bed is by day a narrow seat with overhanging bookcases; by night it swivels out to accommodate the sleeper... Here, too, everything is contrived to fold away into the dignity of unvarnished pinewood. And in the bathroom as well, nothing need be seen, nothing need be left lying about. The bed-supports, the door... they are made of such pinewood as one may never see again in a modest bachelor apartment. (14-15)

On another occasion, a snack on the plane is also given detailed depiction:

It is a mid-morning compromise snack composed of salami on lettuce, two green olives, a roller-up piece of boiled ham containing a filling of potato salad ad a small pickled something, all laid upon a slice of bread. There is also a round cake, swirled with white and chocolate cream, and a corner of silver-wrapped processed cheese with biscuits wrapped in cellophane. An empty plastic coffee cup stands by on each of their trays. (31)

In addition to the above-mentioned, the pavilion around which Lise chooses to be murdered and the other places are depicted in full detail.

In The Driver's Seat, the objective and detailed descriptions of objects or places are one aspect of impersonal writings, and are characteristic of postmodernist writings. Traditionally, objects or places are usually described in a novel to help reveal the author's feelings, facilitate the development of the story, etc. They tend to be the clues of the story and indicate the author's emotions. But here in the novel, things are only described in a rather objective way without implying any of the author's or character's feelings and emotions. The descriptions quoted display a sense of detachment in that they don't in the least disclose anything about the character's or the author's thoughts, feelings, or motivations, without the description of which the novel appears to lack in depth. The lack in the depth pattern is one of the important features of postmodernist writings.

Another aspect of Spark's impersonal writing is the presentation of the near anonymity of the protagonist, which conveys the lack of explicit feelings and emotions on the author's part. Everything contributes to the fact that she is almost anonymous. In her novels, the text refuses notoriously to offer the reader the protagonist's motivation or history. The Driver's Seat is exemplary of these novels. Even the protagonist's full name is not provided. As is known, the very beginning of the novel doesn't, as the conventional novels would, furnish the name of the protagonist. She is only referred to as "the young woman," "she," or "the customer." It is only after the incident comes to an end and the scene shifts to the protagonist's office that the reader, from her immediate superior's greeting, knows about her name which is but the first name: "You've got your packing to do, Lise. Go home, pack and rest" (9). Judging from the purposeful delay in providing the name or from Spark's reluctance to give it, one may guess that if it were not for the smooth development of the novel, Spark would not give the protagonist's name. From beginning to end, the protagonist is just known by that simple name, which seems to imply that the name is of little importance. What's more, Lise's history or her social condition is merely briefly mentioned: she is working in an accountant office; she has seven subordinates and seven superiors as well: five girls under her and two men. Over her are two women and five men (9). Spark doesn't tell the exact age of Lise: She might be as young as twenty-nine or as old as thirty-six, but hardly younger, hardly older (18); Nor does Spark provide any information concerning her family or relationships, except that at one time, Lise makes up a story about going to meet her boy-friend in the other city. Nor are the country where she comes from and the place she will travel to made clear to the reader, for when Mrs. Fiedke asks where Lise's home is, Lise only answers "Nowhere special," and continues with "It's written on the passport"(54). Her ability to speak four languages, namely, Danish, 
French, Italian, and English, further confuses readers as to what her nationality is and seems to indicate that there is no sense of even a mother tongue for her-they can only guess that Lise is from a northern city named Copenhagen, and will go to an unspecified southern city.

The anonymity on the one hand, reflects one aspect of Spark's impersonal writings and shows her concern with the postmodern society where great changes are taking place all the time, and on the other hand, conveys a sense of obvious absence, a feeling of omission, which is typical of postmodernist writings.

The places where the story takes place also demonstrate features of Spark's impersonal writings. Most of the actions take place in public locations, such as department stores, airport terminals, the streets, the park, and the aeroplane. Some happen in private locations, like the hotel bedrooms and Carlo's garage. Both these locations have little imprint of individual human personality, which involves the least personal feelings or emotions.

"The rejection of pathetic fallacy" also applies to the descriptions of Lise's facial features and the bell pushes in her hotel room, etc, which highlights Spark's impersonal attitude, because they are only flatly described. Owing to the repetition of details and the over precision produced by the repetition, Spark's postmodernist art is evident. In the case of Lise's features, Spark writes:

Her lips are slightly parted; she, whose lips are usually pressed together with the daily disapprovals of the accountants' office where she has worked continually... Her lips, when she does not speak or eat, are normally pressed together like the ruled line of a balance sheet, marked straight with her old-fashioned lipstick, a final and a judging mouth, a precision instrument, a detail-warden of a mouth...(9)

As the reader goes on, he will find out easily that Lise's lips are repeatedly described for at least sixteen times (on my count) and they are usually described as "slightly parted" or "form a straight line." By the monotonous and repeated depiction of the lips, Spark imparts to the reader her impersonal attitude toward Lise, for it seems that she cares little about Lise except for her lips. Such consistent repetitions of simple, particular and flat descriptions typically echo Robbe-Grillet's fictional manner in The Driver's Seat, and they are paradigmatic of postmodernist art. The bell-pushes also attract the reader's attention with the detailed descriptions:

By the side of the bed is a small oblong box bearing three pictures without words to convey to client of all languages which bell-push will bring which room attendant. Lise examines this with a frown, as it were deciphering with the effort necessary to those more accustomed to word-reading the three pictures which represent first a frilly maid with a long-handled duster over her shoulder, next a waiter carrying a tray and lastly a man in buttoned uniform bearing folded garment over his arm. (46)

The other objects that receive meticulous descriptions include the stain-resistant dress Lise is buying, the snack on the plane and Lise's apartment. These descriptions of objects occupy a large proportion of the novel and play vital part in it. The more detailed treatments of such objects, the better Spark's impersonal sense of writings is imparted. With the descriptions, Spark apparently is following the advice of Robbe-Grillet who conceives as one major task of fiction the dispassionate description of the external world which acts as a substitute for the traditional novel's concern with character.

In addition to the detailed depictions concerning the trivial matters, some ordinary processes are narrated with fastidious precision. Once, after she enters the hotel room,

Lise slides open the cupboard, pulls down a wooden hanger and throws it across the room with a clatter, then lies down on the bed... She opens her suitcase and carefully extracts a short dressing-gown. She takes out a dress, hangs it in the cupboard, takes it off the hanger again, folds it neatly and puts it back. She takes out her sponge-bag and bedroom slippers, undresses, puts on her dressing-gown and goes into the bathroom, shutting the door. (47)

On another occasion, when Lise is waiting at the rest-room, she attempts to arrange in order things in her zip-bag:

There is an unsealed paper bag which she peers into; it is the orange scarf. She puts it back into place and takes out another bag containing the black and white scarf. She folds this back and with her lipstick she traces on the outside of the bag in large capitals, "Olga"... She feels round it with half-closed eyes for a moment, then opens it up... Lise wraps them up again and replaces them. (85)

In the above instances, Lise's movements are robot-like and the lack of syntactical variety is apparent; also evident is the fact that epithets are seldom used in the paragraphs. These convey a sense of monotonousness and suggest Spark's obvious detachment in sending out the hint that this is a clinical world without color. As a result, her impersonal attitude is properly conveyed to the reader.

In the novel, Spark is enlightened by the leading light of the nouveau roman-Alain Robbe-Grillet. Lise's feelings are 
never clearly indicated and no emotion is revealed. It is as if a camera were following her and recording what is happening - her behavior is merely described, or is reported rather than being explained. For example, she severely blames the attendant at the hotel for leaving a tooth-glass in her room with an unused Alka Seltzer in it; she endeavors to put in order her bag with utmost care at the restroom; she examines carefully the map of the town that she is paying a brief visit to. The reader can never make out what her true intentions are and they have to make wild guesses at them in order to understand her bizarre speeches and behaviors, just as the author writes in the novel: "Who knows her thoughts? Who can tell?" (50). Judy Sproxton points out that the style of the account is also as eccentric as Lise and it is in the present tense, which stresses the narrator's detachment as each moment is carefully chosen without comment. (Sproxton, 1992: p. 137)He also asserts that "nowhere in Muriel Spark's work is a character presented so remotely as Lise in The Driver's Seat" (Sproxton, 1992: p.137). Through the remote presentation of Lise, Spark effectively demonstrates her impersonal writings. Moreover, the effect of over precision induced by the detailed and careful description demonstrates the postmodernist flavour of Spark's strategy.

As a result of the impersonal writings, Lise's personality is merely blandly presented. Thereupon, she has not any interesting or appealing characteristics, and is not identified with. In the novel, because of the lack of interest in or the indifference toward her, no one has cared about Lise. Death has been mentioned for several times, but the reader is not affected by that at all, and even her final death does not make much impact. Lise as the protagonist seems to be a remote outsider to the author and the reader, as Sproxton holds that "in no other of Muriel's books are both narrator and the reader so far outside the central character" (Sproxton, 1992: p. 154). Lise is described with such little feeling or emotions on the author's part that she is almost dehumanized, which leads to her unavoidable destruction, as Judy Little says, "In a world that dehumanizes people and turns them into objects, such manic obsessions and self-destruction are inevitable"(Little, 1983: p. 154).

The effects of the impersonal writings in The Driver's Seat are so impressive that they not only distance the author, but also distance the reader from Lise who is alienated from the society. The distancing strategy adopted by Spark enables the reader to enjoy the reading without the distraction of any emotions, of either horror or disgust. Thus, the reader can fully concentrate on and actively participate in the reading and interpretation of the novel, which renders it a "writerly" text rather than a "readerly" text. Thus from this perspective, the impersonal writings of Spark in the novel demonstrate some typical postmodernist characteristics. Another advantage of the impersonal writings here is that it corresponds to the content and the theme of the novel. It complies with the atmosphere of Lise's journey to seek for her own death and is in accordance with Lise's determination for self-destruction. In a world where the emotion is on the brink of exhaustion, and the individual meanings get lost in the spiritual wasteland, the society is sure to be thrown into disorder and people have to pluck up their courage to confront this predicament. Spark shows that the best way to tackle with such a dilemma is to adopt an impersonal attitude on the part of the author, and leave the problem of making judgments to the reader.

\section{The Rejection of the Sequential Plot}

In The Driver's Seat, Spark, as the new novelists do, purposefully rejects the sequential plot. She mainly achieves her aim of the rejection by resorting to two devices, namely the application of the present tense and the employment of flash-forwards combined with the third person narrative. By rejecting the sequential plot, Spark disrupts the chronological order of the story, thus offering the reader a demonstration on how the narrative is constructed instead of just the orderly and logical narrative in the conventional novel. In this way, she foregrounds the artificial construct of the novel, and keep the reader aware of the novel as an artifact. Therefore, it reflects Spark's concern with the creation itself and thus the ontological status of the novel is exposed, which is one typical quality of postmodernist fiction. In the case of modernist fiction, sometimes the sequential plot is also rejected, but it is in accordance with the psychological time of the author and this device is usually applied in monologues or the stream of consciousness novels.

One major feature of the nouveau roman is the rejection of the sequential plot, as John Sturrock proclaims that "The plot is no longer so confident or coherent... What the New Novel (also called the nouveau roman) is depriving its readers of are the consolations of a mechanistic sequence of events, with its confident marriage of causes with effects..."(Sturrock, 1969: p. 9). When Chris Baldick defines the nouveau roman, he cites the sequential plot as one of the elements that are rejected by the new novelists. This viewpoint corresponds to that of Ann Jefferson in her The Nouveau Roman and the Poetics of Fiction. In it, she refers us to Robbe-Grillet's and Nathalie Sarraute's views concerning the traditional view of plot. Robbe-Grillet maintains that the conventional order and coherence of the plot presents a false view of the world as intelligible and in good order for the elements of narrative - the use of third person narrative, the unconditional adoption of chronological development, linear plots, etc. - are all designed to give an image of a coherent, stable, continuous, and unambiguous universe. Similarly, Sarraute regards the plot as an artificial form of representation, and she even claims that we should dispense with narrative because we see time cease to be the rapid current which carries the plot forward to become instead a stagnant pool... we see our actions lose their usual motives 
and their accepted meanings. (Jefferson, 1980: p. 15-16) Accordingly, in showing their disagreement on the traditional view of plot, the new novelists attach importance to the rejection of the sequential plot.

The rejection of the sequential plot is just one conspicuous characteristic of The Driver's Seat, which is mainly represented through the dominant use of the present tense and a special technique of time shift called "flash-forward." Ann Jefferson, when talking about the use of the present tense in L"Emploi du Temps, contends that "the recognition of the present tense of narration made a linear cause-and-effect model of narrative impossible to adhere to and gives rise to an image of a different narrative order," and, at the end of the passage, she argues that "successivity, linearity and causality are replaced by an attempt at simultaneity" (Jefferson, 1980: p. 38). Accordingly, the present tense plays a crucial role in presenting "an image of a different narrative order," which, in the case of The Driver's Seat, refers to the uncommon plot of the novel that is not sequential as required by the conventional practice. In The Driver's Seat, Muriel Spark adopts the present tense combined with the third person narration throughout the whole novel, except for a few places where the future tense is appropriated. Nevertheless, a story is conventionally narrated in the past tense, on the one hand to indicate that the story has already taken place and thus makes it more credible; on the other hand, to demonstrate the author's omniscient vantage point on or dominance over the novel.

The adoption of the present tense in The Driver's Seat is evident and contributes a lot to the rejection of the sequential plot. It shows Robbe-Grillet's influence on The Driver's Seat. The use of the present tense is of considerable significance: firstly, it subverts the common concept of time held by the traditional novelists in that it no longer makes the story move smoothly in a linear way, or in a chronological order, for from time to time, the story presents the reader with the narration of some future dialogues or future actions of the characters which disrupt the sequential development of the story. Secondly, the adoption of the present tense seems to indicate that what happens now does not necessarily belong to the past, the future, or even to the present. The story takes place all the time, no matter whether it is in the past, at present or in the future. In fact, it takes place at any time, to some extent. The phenomena in the story appear all the time. So the present tense evokes in the reader a sense of eternality in terms of the phenomena in the story. Thirdly, the present tense enables Spark to freely make use of the future tense in the story so as to give full play to the technique of flash-forwards.

As an extremely important and very distinguishing narrative device, flash-forwards time and again appear in Muriel Spark's novels, such as The Prime of Jean Brodie (1961), Not to Disturb (1971), The Hothouse by the East River (1973). Actually, "flash-forward" is more formally recognized as "prolepsis," a Greek word for "anticipation." In Oxford Concise Dictionary of Literary Terms, Chris Baldick writes that prolepsis, when used in narrative works, is a "flash-forward" by which a future event is related as an interruption to the "present" time of the narration. After citing a passage from Muriel Spark's The Prime of Miss Jean Brodie about the schoolgirl Mary, Baldick declares that in this sense, prolepsis is an anachrony that is the opposite of flashback or analepsis. (Baldick, 2000: p. 178-79)

The use of flash-forwards is one effective means of rejecting the sequential plot of the novel and it can be attributed to the change in our concept of time, as Ann Jefferson writes:

There has been a change in our notion of the experience of time, for example, so that the linearity of plot now seems a false representation of time. Instead, we can read the confused chronological structure of many of the nouveaux romans as a more appropriate representation of the experience of time, a formal equivalent of what Sturrock calls the "play of the mind"... (Jefferson, 1980: p. 384)

Accordingly, we may regard Spark's "play of mind" as responsible for the existence of many flash-forwards in The Driver's Seat. She, at the expense of the commonly accepted principle of causality as well as the disruption of her narration, attempts to alert the reader to the question of "why it happens" or "how it happens" other than "what happens." In an interview, Spark offers her reasons of rejecting the chronological order, or rejecting the sequential plot:

What interests me about time is that I don't think chronology is causality. I don't think that the cause of things necessarily comes hours, moments, years before the event; it could come after, without the person knowing. For instance in Not to Disturb, the servants know absolutely beforehand what's going to happen... This is not realism, you know. In The Driver's Seat, Lise knows exactly what she's going to do, although she sniffs around a lot, looking for it—but in fact she's just going straight to see a man who's got tendencies to kill, and he will kill her. In the end she just goes up to him and says, "You're coming with me," it's nearly midnight by that time.... (Frankel, 1987: p. 451-52)

The change in our idea of time, which leads to the rejection of sequential plot, occupies the concern of many critics. In "Parodying Postmodernism: Muriel Spark and Robbe-Grillet," Aidan Day discusses the difference of temporal concepts between the nouveau roman and the traditional novels. She quotes Robbe-Grillet's words as follows: 
In the modern narrative, time seems to be cut off from its temporality. It no longer passes. It no longer completes anything... Description makes no headway, contradicts itself, turns in circles. Moment denies continuity. (Day, 2007: p. 325)

Also introduced in the essay is Elizabeth Ermarth's view that a subversion of historical time is a principal feature of postmodernism's promise of liberation from oppressive cultural codes:

For centuries, historical time, with its linked past and future, has made possible the articulation of certain "laws" of development and has been a cultural absolute from physics to politics to narrative... Postmodern novelists begin their primary task of reformulating temporality by showing readers that such an idea of temporality is a convention... not a condition of nature... Postmodern narrative, in short, calls our attention not to fictions of origins and ends, but to the process of consciousness itself as it constructs and deconstructs such fictions. (Day, 2007: p. 325)

Spark, with her use of the device of flash-forwards, attracts our attention to her process of consciousness in the unfolding of the story of The Driver's Seat. The flash-forwards, or the time shifts, at first sight, seem to be a bit abrupt and unexpected in the middle of the story and hinder the smooth development of the narration, but when we reach the end or when we examine them on the second reading, we find out that they partake of a special logic. They display Spark's consciousness, or the workings of her mind. As a result, we, as readers, are stimulated by Spark's time device and are more determined to explore into the author's mind as well as to construct a logical version of the whole story. What's more, we, alerted to the special time sequence, may concentrate on what occurs, paying attention to every word in it, lest any clue of importance should get neglected.

Altogether, there are nine flash-forwards on my count in the novel. The first flash-forward comes at the airport when Lise is waiting to have her bag weighed-in. She is described as someone plain:

She is neither good-looking nor bad-looking. Her nose is short and wider than it will look in the likeness constructed partly by the method of identikit, partly by actual photography, soon to be published in the newspapers of four languages (18).

At first sight, we don't know why her photo will appear in the newspapers of four languages. This continues to puzzle and interest us until we know that she will be murdered and in order to find out her identity, the police have to put her photo in the newspaper. As to why it appears in newspapers of four languages, the reader has to wait until later to know the answer: It is because she, according to some people she has contacts with, speaks four languages, which makes it difficult for the police to determine which is her mother tongue and they have to resort to newspapers of four languages to get more clues from some possible witnesses. Thus, the appearance of her photo in the newspaper becomes the suspense. The brief switch from the present tense to the future tense tells the reader what will happen and raises their curiosity, as Spark states in an interview, 'I think suspense is often heightened if the author 'gives away' the plot from the very beginning. The reader is then all the more anxious to find out how the conclusion came about. I adopted this method in my book The Driver's Seat" (Hosmer, 2005: p. 146).

The next flash-forward follows very soon, and is involved with a stranger from Johannesburg whom Lise meets at the bookstall. She later acts as a witness to the police:

She (the woman from Johannesburg) smiles and is amiable in this transient intimacy with Lise, and not even sensing in the least that very soon, after a day and a half of hesitancy, and after a long midnight call to her son, the lawyer in Johannesburg, who advises her against the action, she nevertheless will come forward and repeat all she remembers and all she does not remember, and all the details she imagines to be true and those that are true, in her conversation with Lise when she sees in the papers that the police are trying to trace who Lise is, and whom, if anyone, she met on her trip and what she had said. (23)

Similar to the first flash-forward, this one keeps confusing us until we know that Lise is murdered later and the woman will help the police to get some traces of her.

The third flash-forward gives away the fate of Lise or the end of the story, and solve the mystery that the first and the second flash-forward bring us. It presents what will happen to Lise:

She will be found tomorrow morning dead from multiple stab-wounds, her wrists bound with a silk scarf and her ankles bound with a man's necktie, in the grounds of an empty villa, in a park of the foreign city to which she is traveling on the flight now boarding at Gate 14. (25)

What follows this passage is the narration in the present tense of Lise's actions when crossing the tarmac to the plane. The story swings between the two time elements-Lise's actions before boarding the plane, put into the present tense, and the description of the aftermath of Lise's murder put into the future tense - and seem incompatible at first sight. 
However, Spark does this on purpose. When being asked about this early give-away, Spark answers: "That device is quite deliberate. To give the show away in a strange way, strange manner creates suspense more than the withholding of information does. Secondly, I think that it has an eschatological function, as you indicate-mentioned-before" (Hosmer, 2005: p. 150). Besides the two functions listed by Spark, the flash-forward which reveals the end of Lise diverts the reader's attention from the plot, or from "what happens", to "how it happens" and "why it happens", and to the theme of the novel or the motivation of Lise. When commenting on this flash-forward, Bradbury claims that "not only the reader, but also Lise, knows the ending, this is Lise's victory" and "in the chaotic run of the present she has always known a future"(Bradbury, 1972: 249). Consequently, the suspense comes not in seeking out what happens to Lise, for the reader already knows the end. The thing for them to find out is how the author constructs the intricate plot that follows. In fact, the flash-forwards which are the means to reject the sequential plot in the novel, when combined with the third person narrative, turn out to be the typical postmodernist strategy employed by Muriel Spark, as David Lodge says:

Muriel Spark's combination of frequent time-shift with authorial third-person narrative is a typical postmodernist strategy, calling attention to the artificial construction of the text, and preventing us from "losing ourselves" in the temporal continuum of the fictional story or in the psychological depth of the central character. (Lodge, 1991: p. 77)

Flash-forward five, six and seven concern a waiter, a policeman, and some garbage men. They are, like the woman from Johannesburg in flash-forward two, witnesses who have brief contacts with Lise and are to offer the police some clues as to the actions and the identity of Lise. The design of these flash-forwards by Spark, on the one hand, enables the reader to better understand the aim of Lise - to leave some clues here and there; on the other hand, it explains the intentions of the author to arrange those subplots.

The rest of the flash-forwards, namely flash-forwards four, eight, and nine, are all concerned with the murderer Richard. They describe in detail his arrest and interrogation after he murders Lise. As early as the fourth flash-forward, Richard's fate is already known, for he will be in custody while the murder case is under investigation:

On the evening of the following day he will tell the police, quite truthfully, "The first time I saw her was at the airport. Then on the plane. She sat beside me."

"You never saw her before at any time? You didn't know her?"

"Nothing. I moved my seat. I was afraid." (Richard's words)

"Yes, frightened. I moved to another seat, away from her." (Richard's words)

"What frightened you?" ...(27)

This early give-away disrupts the sequential movement of the story, and utterly subverts people's expectation of this "detective story" which is, in fact, a parody of the traditional detective story in which the murderer is usually found out at the end of the story. This parody in the text again demonstrates the novel's postmodernist feature. Flash-forward eight makes the interrogation of Richard more vivid:

The morning will dawn, and by the evening the police will place in front of him the map marked with an $\mathrm{X}$ at the point where the famous Pavilion is located, the little picture. ... They will reveal, bit by bit, that they know his record. They will bark, and exchange places at the desk. They will come and go in the little office, already beset by inquietude and fear, even before her identity is traced back to where she came from.... Round and round again will go the interrogators, moving slowly forward, always bearing the same questions like the whorling shell of a snail. (105)

With this, the tragic life of Richard is in evidence. Spark seems to indicate that before man is doing anything, the result is already predestined.

The flash-forwards demonstrate the authorial interventions to the depiction of events in reality, and create a series of dislocations. In discussing the time shifts, David Lodge says something about the effects produced by the use of time shifts and the intervention of the authorial voice which is also appropriate to the flash-forwards: "...constantly check any inclination we may have to 'lose ourselves' in the story or to sink into emotional identification with any of the character; it detaches us from the experience presented and makes us think about its meaning, or meanings" (Lodge, 1971: p. 126). When the reader is thinking about the meanings of the novel, he may be naturally attracted to the artificial construction of the novel. Then the postmodernist characteristic of The Driver's Seat is exposed through the use of flash-forwards that lead to the rejection of the sequential plot.

\section{Conclusion}


With the impersonal narration and the rejection of the sequential plot, Spark's The Driver's Seat displays the typical features of the nouveau roman as well as the postmodernist fiction and turns out to be a brilliant success, as Ian Rankin claims: "Like Robbe-Grillet's The Erasers, Spark's book deals with the day leading up to a murder with all its coincidences and intricacies. It is in matters of technique, however, that The Driver's Seat can be seen as the most successful nouveau roman in English"(Rankin, 1985: p.154). The adoption of Robbe-Grillet's devices and Spark's own metacommentary on the devices "amount to a critical engagement with postmodern assumptions and perspectives" (Day, 2007: p. 322).

\section{Notes}

1. Muriel Spark, The Driver's Seat (Middlesex: Penguin, 1970) 107. The references cited are all to this edition and the page numbers are included in the parentheses in the following texts.

\section{References}

Bradbury, M. (1972). Muriel Spark's Fingernails. Critical Quarterly, 14, 241-250. http://dx.doi.org/10.1111/j.1467-8705.1972.tb02059.x

Day, A. (2007). Parodying Postmodernism: Muriel Spark (the Driver's Seat) and Robbe-Grillet (Jealousy). English, 56(216), 321-337. http://dx.doi.org/10.1093/english/56.216.321. (http://english.oxfordjournals.org/content/56/216/321.extract)

Edmund J. S. (1991). The Nouveau Roman: Modernity and Postmodernity. In Edmund J. S. (Ed), Postmodernism and Contemporary Fiction, 54-73. London: Batsford Ltd.

Grillet, A. R. (1970). Towards a New Novel. trans. Barbara Wright. London: John Calder.

Herman, D. (Fall 2008). "A Salutary Scar”: Muriel Spark's Desegregated Art in the Twenty-First Century. Modern Fiction Studies, 54(3), 473-486. http://dx.doi.org/10.1353/mfs.0.1548. (https://muse.jhu.edu/journals/modern_fiction_studies/toc/mfs.54.3.html)

Hosmer, R. (Spring 2005). An Interview with Dame Muriel Spark. Salmagundi, 146/147, 127- 158. HTTP://DX.DOI.ORG/10.1080/00497870490890825(http://www.tandfonline.com/doi/abs/10.1080/004978704908 90825? journalCode $=$ gwst20)

Jefferson, A. (1980). The Nouveau Roman and the Poetics of Fiction. Cambridge: Cambridge University Press.

Kermode, F. (September 1970). Sheerer Spark. Listener, 24, 425.

Little, J. (1983). Comedy and the Woman Writer: Woolf, Spark and Feminism. Lincoln: Nebraska Press.

Lodge, D. (1991). The Art of Fiction. London: Penguin Books.

Lodge, D. (1971). The Uses and Abuses of Omniscience: Method and Meaning in Muriel Spark's The Prime of Miss Jean Brodie. In Lodge D. (Ed), The Novelist at the Crossroads and Other Essays on Fiction and Criticism, 119-144. London: Routledge.

Rankin, I. (1985). Surface and Structure: Reading Muriel Spark's the Driver's Seat. Journal of Narrative Technique, 15(1), 146-155.

Sarraute, N. (1963). Tropisms and the Age of Suspicion, trans. Maria Jolas. London: John Calder.

Sproxton, J. (1992). The Women of Muriel Spark. New York: St. Martin's Press.

Sturrock, J. (1969). The French New Novel. London: Oxford University Press.

\section{$(\mathrm{cc}) \mathrm{Br}$}

This work is licensed under a Creative Commons Attribution 3.0 License. 